\title{
Reversion of apoptotic resistance of TP53-mutated Burkitt lymphoma B-cells to spindle poisons by exogenous activation of JNK and p38 MAP kinases
}

\author{
M Farhat ${ }^{1}$, A Poissonnier ${ }^{1}$, A Hamze ${ }^{2}$, C Ouk-Martin ${ }^{1}$, J-D Brion ${ }^{2}$, M Alami ${ }^{2}$, J Feuillard ${ }^{1,3}$ and C Jayat-Vignoles ${ }^{*, 1}$
}

Defects in apoptosis are frequently the cause of cancer emergence, as well as cellular resistance to chemotherapy. These phenotypes may be due to mutations of the tumor suppressor TP53 gene. In this study, we examined the effect of various mitotic spindle poisons, including the new isocombretastatin derivative iso $\mathrm{NH}_{2} \mathrm{CA}-4$ (a tubulin-destabilizing molecule, considered to bind to the colchicine site by analogy with combretastatin A-4), on BL (Burkitt lymphoma) cells. We found that resistance to spindle poison-induced apoptosis could be reverted in tumor protein p53 (TP53)-mutated cells by EBV (Epstein Barr virus) infection. This reversion was due to restoration of the intrinsic apoptotic pathway, as assessed by relocation of the pro-apoptotic molecule Bax to mitochondria, loss of mitochondrial integrity and activation of the caspase cascade with PARP (poly ADP ribose polymerase) cleavage. EBV sensitized TP53-mutated BL cells to all spindle poisons tested, including vincristine and taxol, an effect that was systematically downmodulated by pretreatment of cells with inhibitors of p38 and c-Jun N-terminal kinase (JNK) mitogen-activated protein kinases. Exogenous activation of p38 and JNK pathways by dihydrosphingosine reverted resistance of TP53-mutated BL cells to spindle poisons. Dihydrosphingosine treatment of TP53-deficient Jurkat and K562 cell lines was also able to induce cell death. We conclude that activation of $\mathrm{p} 38$ and JNK pathways may revert resistance of TP53-mutated cells to spindle poisons. This opens new perspectives for developing alternative therapeutic strategies when the TP53 gene is inactivated.

Cell Death and Disease (2014) 5, e1201; doi:10.1038/cddis.2014.150; published online 1 May 2014

Subject Category: Cancer

Among underlying causes of cancer is accelerated or deregulated proliferation, with alteration of key cell cycle regulators and perturbation of proliferative negative retrocontrols such as cell cycle checkpoints or DNA damage response. Another driving force of cell transformation is aberrant cell survival, a consequence of the inability to undergo apoptosis. Many cancer treatments stop tumor progression by inducing DNA damage and/or by perturbation of mitosis, then inducing apoptosis by activation of stress cell signals. $^{1}$

Apoptosis induced by cellular stress is often mediated by the intrinsic mitochondria-initiated cell death pathway. ${ }^{2}$ This pathway, regulated by the members of the Bcl2 family, converges on Bax and Bak activation by $\mathrm{BH} 3$-only subgroup of Bl2-related proteins (such as Bim, Bmf, Bid, p53 upregulated modulator of apoptosis (PUMA) or Noxa). Activation, relocalization to the mitochondria and polymerization of Bax and Bak, as well as their association with the anti-apoptotic molecules $(\mathrm{Bcl} 2, \mathrm{Bcl}-\mathrm{xl}$ or myeloid cell leukemia sequence 1 (Mcl1)), induce outer mitochondrial membrane permeabilization and release of apoptogenic factors, such as cytochrome c, apoptosis-inducing factor, Smac/DIABLO (second mitochondria-derived activator of caspase/direct inhibitor of apoptosis protein (IAP)-binding protein with low pl) or Omi/ $\mathrm{HtrA} 2$ (Omi/high temperature requirement protein A). ${ }^{3}$ In the cytosol, the apoptosome complex (cytochrome c/Apaf1/ caspase 9) triggers activation of caspase 9 and therefore the caspase cascade. ${ }^{3}$ Smac/DIABLO and Omi/HtrA2 promote caspase activation by binding to IAP. ${ }^{3,4}$

By blocking mitosis at the M-phase, spindle poisons are stress signal inducers. These molecules, which are antineoplastic drugs, exert their activity through activation of the spindle assembly checkpoint, thereby arresting cells in mitosis. Prolonged mitotic arrest leads to activation of the protein kinase p38, c-Jun N-terminal kinase (JNK) and caseine kinase II, which, in turn, result in phosphorylation

\footnotetext{
${ }^{1}$ Univ Limoges, Faculté de Médecine, CNRS UMR 7276, Laboratoire CRIBL, Limoges, France; ${ }^{2}$ Univ Paris Sud, Faculté de Pharmacie, CNRS UMR 8076, Laboratoire BioCIS, Châtenay Malabry, France and ${ }^{3} \mathrm{CHU}$ Limoges, Hôpital Dupuytren, Service d'hématologie, Limoges, France

*Corresponding author: C Jayat-Vignoles, Faculté de Médecine, UMR CNRS 7276, 2, rue du Dr Marcland, Limoges 87000, France. Tel: +33 55 5435 867; Fax: +33 555435 897; E-mail: chantal.vignoles@ unilim.fr

Keywords: TP53 mutation; spindle poisons; iso $\mathrm{NH}_{2} \mathrm{CA}-4$; MAP kinases; EBV

Abbreviations: ACVBP, adriamycin, cyclophosmamide, vindesine, bleomycin, prednisone; BL, Burkitt lymphoma; CA-4, combretastatin A-4; CHOP, cyclophosmamide, hydroxydaunorubicine (adriamycin), oncovin (vincristine), prednisone; CLL, chronic lymphocytic leukemia; DAPI, 4',6-diamidino-2-phenylindole; DIABLO, direct inhibitor of apoptosis protein-binding protein with low pl; DiOC6(3), 3,3'-dihexyloxacarbocyanine iodide; DMSO, dimethyl sulfoxide; EBV, Epstein Barr virus; FLICA, fluorochrome-labeled inhibitors of capases; $\mathrm{H} 2 \mathrm{AX}, \mathrm{H} 2 \mathrm{~A}$ histone member X; HtrA2, high temperature requirement protein A; JNK, c-Jun N-terminal kinase; LMP, latent membrane protein; MAP kinase, mitogen-activated protein kinase; Mcl1, myeloid cell leukemia sequence 1; MDM2, mouse double minute 2 homolog; MTS, (3-(4,5-dimethylthiazol-2-yl)-5-(3-carboxymethoxyphenyl)-2-(4-sulfophenyl)-2H-tetrazolium salt; PARP, poly ADP ribose polymerase; PUMA, p53 upregulated modulator of apoptosis; PRIMA, 2,2-bishydroxymethyl-1-aza-bicyclo[2.2.2]octan-3-one; PTPC, permeability transition pore complex; RITA, 5,5'-(2,5-furandiyl)bis-2thiophenemethanol; Smac, second mitochondria-derived activator of caspase; TP53, tumor protein p53

Received 09.12.13; revised 20.2.14; accepted 21.2.14; Edited by H-U Simon
} 
and degradation of the anti-apoptotic protein Mcl1 and prevent Bax and Bak polymerization at the mitochondria membrane. ${ }^{5}$ Long-term mitotic arrest also induces inhibition of $\mathrm{Bcl} 2$, also mediated by JNK phosphorylation. ${ }^{6}$

Spindle poisons are classified into two categories, those that stabilize the microtubules, like taxanes, and those that bind to the colchicine domain (such as colchicine) or to vinca domain (vinca alkaloids such as vincristine, vinblastine or vindesine) and destabilize tubulin microtubules. ${ }^{7,8}$ Binding of these molecules to $\beta$-tubulin disturbs microtubule dynamics when the mitotic spindle is formed and disassembles the cytoskeleton during cell division. Classical chemotherapy protocols very often include spindle poisons, such as vincristine or vindesine for hematological disorders (polychemotherapy CHOP: cyclophosmamide, adriamycin, vincristine, prednisone or ACVBP: adriamicin, cyclophosmamide, vindesine, bleomycin, prednisone), ${ }^{9}$ or taxanes for solid tumors. ${ }^{10}$ However, synthesis of these antimitotic agents is complex and in addition they have numerous toxic side effects like peripheral neuropathy, neutropenia and diarrhea ${ }^{11}$ and emergence of multidrug-resistant phenotypes can be observed. ${ }^{12,13}$

Looking for new and easier ways to synthesize molecules that are less toxic and have different spectrums of action is still valid. Among new recent molecules are combretastatins, particularly combretastatinA-4 (CA-4), which bind to the colchicine domain, exhibit a strong inhibitory effect on tubulin assembly, possess antivascular properties and inhibit cell proliferation at nanomolar concentrations. ${ }^{14} \mathrm{~A}$ soluble prodrug CA-4P (phosphate disodic CA-4) has been developed for use in clinical trials. ${ }^{15}$ But CA-4, characterized by a Z-stilbene structure, is subject to isomerization, with a strong loss of antitumoral effect for the E-isomer compared with the Z-isomer. ${ }^{16}$ A stable analog, iso $\mathrm{NH}_{2} \mathrm{CA}-4$, which is not prone to double-bond isomerization even during storage and administration, has then been synthetized. ${ }^{17}$ Other antimitotic molecules are also in development and in clinical trials and include microtubule-stabilizing or microtubule-destabilizing agents. $7,8,18$

In this study, we wanted to determine the effect of the new combretastatin derivative iso $\mathrm{NH}_{2} \mathrm{CA}-4$ on proliferation of transformed $\mathrm{B}$ cells. Comparing the effect of this new molecule with that of other mitotic spindle poisons, we found that Epstein Barr virus (EBV) infection of tumor protein 53 (TP53)-mutated BL (Burkitt lymphoma) cells reverted resistance to all mitotic spindle poisons. Spindle poisons induced Bax relocalization to mitochondria and caspase cascade activation with PARP (poly ADP ribose polymerase) cleavage in TP53-mutated EBV-infected BL cells. We showed that this fortuitious effect of EBV was related to activation of the JNK/ p38 activation pathways by EBV. Exogenous activation of JNK/p38 pathways by dihydrosphingosine also rendered TP53-mutated EBV-negative BL cells sensitive to spindle poisons, opening new perspectives in bypassing the resistance to these drugs when the TP53 gene was inactivated.

\section{Results}

Spindle poison effects on cell proliferation and apoptosis induction. To test the effect of the isocombretastatin derivative iso $\mathrm{NH}_{2} \mathrm{CA}-4$, we used unmutated (BL2) or mutated
(BL41) BL cell lines for TP53 and their EBV-positive counterparts (BL2B95.8 and BL41B95.8). As control molecules, we used colchicine as the reference for spindle poisons belonging to the colchicine domain binding destabilizing-tubulin molecules and CA-4 as the combretastatin family reference. Iso $\mathrm{NH}_{2} \mathrm{CA}-4$ was the most effective molecule, regardless of cell type. Independantly of the drug used, $50 \%$ inhibition of proliferation was obtained with about twofold less drug for EBV-infected counterparts (Table 1).

We then analyzed the effect of iso $\mathrm{NH}_{2} \mathrm{CA}-4$ on apoptosis, as compared with colchicine and CA-4. Except for BL41, the three drugs induced apoptosis (Figure 1a). Cell cycle analyses were then performed by flow cytometry to estimate the percentage of cells in G2M and sub-G1 phases after 8, 24 or $48 \mathrm{~h}$ treatment by colchicine, $\mathrm{CA}-4$ or iso $\mathrm{NH}_{2} \mathrm{CA}-4$. As expected, accumulation of both BL41 and BL41B95.8 cells in G2M was seen, being earlier for BL41B95.8 cells (Figure 1b). Accumulation of cells in G2M phases without apoptosis was seen for BL41. Meanwhile, BL41B95.8 cells initially accumulated in G2M and then in sub-G1phase (Figure 1b). Similar results to those obtained for BL41B95.8 (accumulation in G2M and then in sub-G1) were observed for BL2 and BL2B95.8 cell lines (data not shown). These results were confirmed by epifluorescence microscopy, after staining of nuclei with propidium iodide. Results are shown for iso $\mathrm{NH}_{2} \mathrm{CA}-4$ in Figure 1c. BL41 cells clearly accumulated in the M-phase without signs of apoptosis, whereas for BL41.B98.5 cells, mitotic accumulation was first observed after $8 \mathrm{~h}$ drug treatment followed by fragmentation of nuclei, a feature of apoptotic terminal events, at $24 \mathrm{~h}$ and later. Similar observations were seen for all spindle poisons (data not shown). Therefore, it appeared that BL41 cells were resistant to apoptosis induction, but not to cell cycle arrest by spindle poisons. Indeed, washing TP53-mutated BL41 cells exposed spindle poisons that allow them to regrow in a new medium (data not shown).

Apoptosis pathway induced by spindle poisons in EBV-infected TP53-mutated BL41 cells. Complementary analyses were performed to characterize apoptosis induced by spindle poisons in BL41B5.8 cells. Treatment of BL41 cells with colchicine, CA-4 or isoNH $\mathrm{N}_{2} \mathrm{CA}-4$ did not induce any caspase 3 and PARP cleavage, whereas both proteins were cleaved in BL41B95.8 cells, suggesting a caspase-dependent apoptotic process (Figure 2a). Similar results to those obtained for BL41B95.8 (caspase 3 and PARP cleavage) were observed for BL2 and BL2B95.8 cell lines (data

Table 1 IC50 values for cytotoxic assays (nM)

\begin{tabular}{lcccc}
\hline Cell line & BL2 & BL2B95.8 & BL41 & BL41B95.8 \\
\hline Colchicine & 30 & 20 & 30 & 20 \\
CA-4 & 20 & 10 & 20 & 10 \\
iso $\mathrm{NH}_{2} \mathrm{CA}-4$ & 10 & 5 & 10 & 5
\end{tabular}

Abbreviation: IC50, half-maximal inhibitory concentration

Spindle poison effects on cell proliferation. IC50 values of MTS cell proliferation assays on BL2- and TP53-mutated BL41 cell lines and their EBV-infected counterparts (BL2B95.8 and BL41B95.8) treated with colchicine, CA-4 or iso NH2CA-4 for $24 \mathrm{~h}$ at concentrations ranging from 5 to $100 \mathrm{nM}$. IC50 values were calculated as means of three values 
a
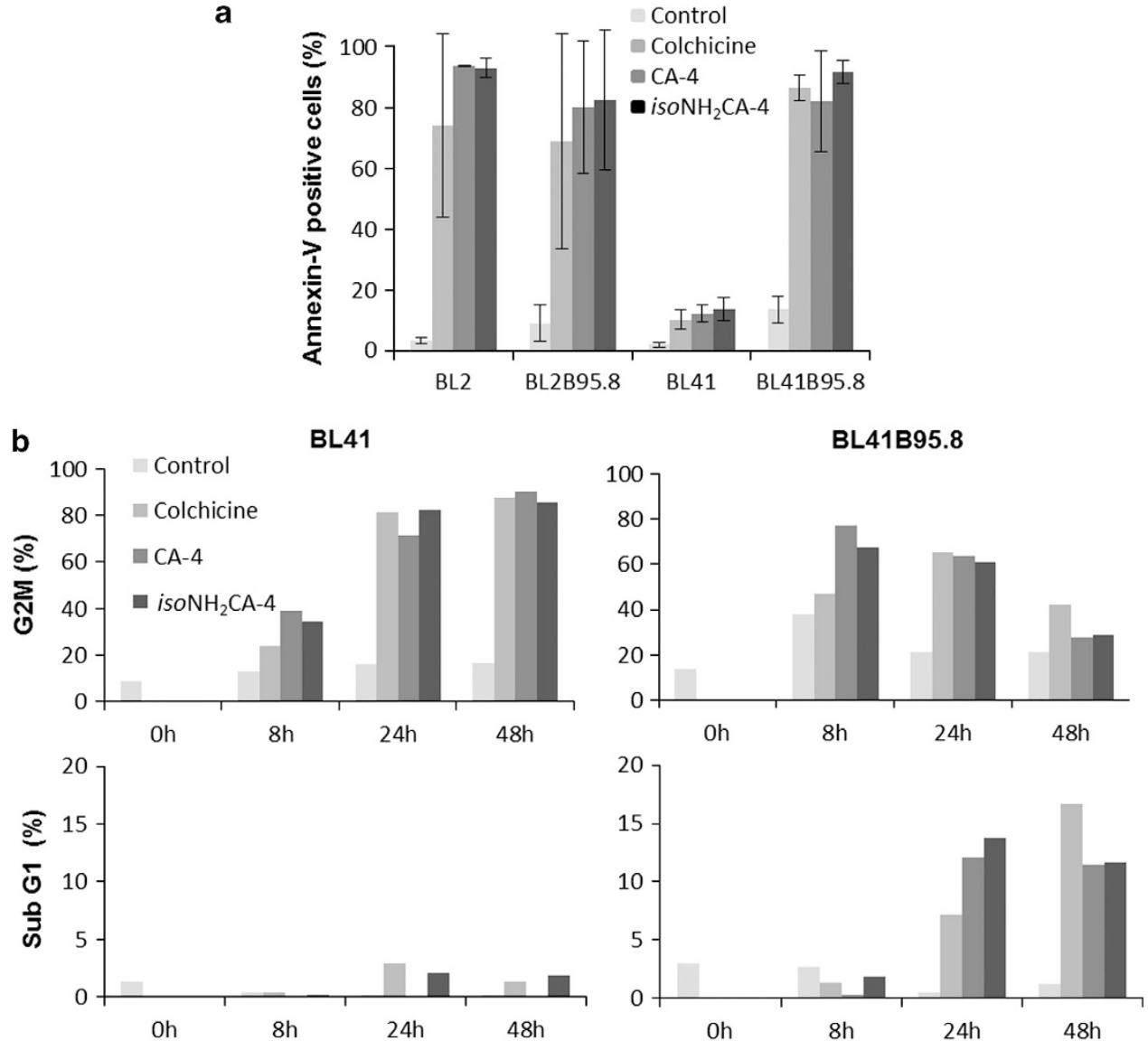

C
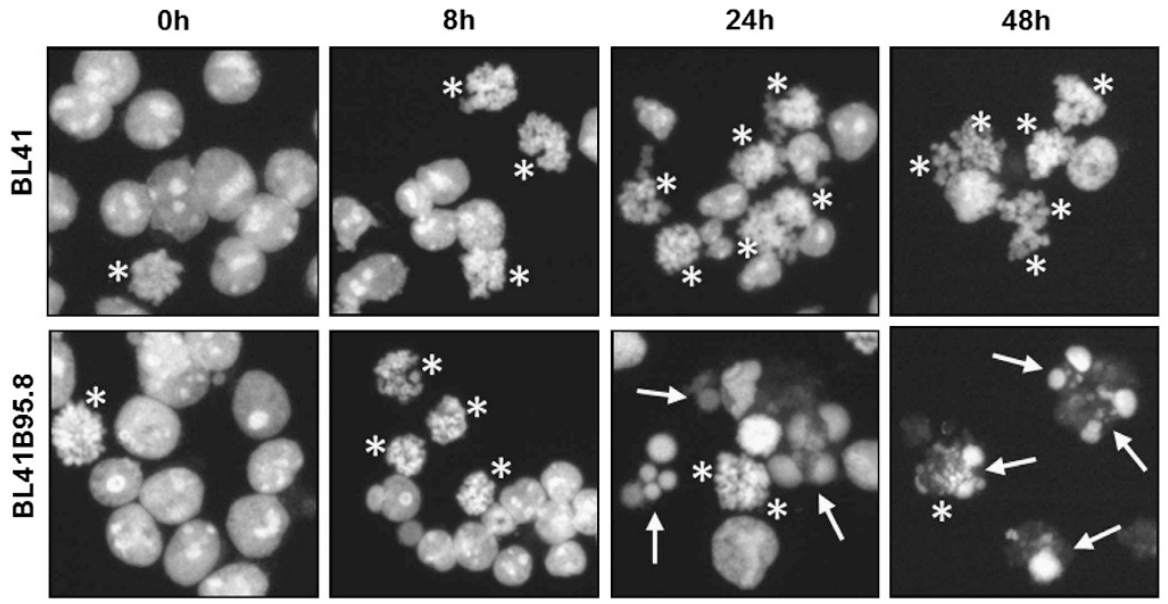

Figure 1 EBV renders TP53-mutated cells permissive to spindle poison-induced apoptosis. (a) Cells were treated with colchicine (20 nM), CA-4 (10 nM) or isoNH ${ }_{2} \mathrm{CA}-4$ $(5 \mathrm{nM})$ for $72 \mathrm{~h}$ (a and $\mathbf{b}$ ). (a) Apoptosis induction was evaluated by flow cytometry after labeling of external phosphatidyl serine residues (Annexin-V-positive cells) on BL2- and TP53-mutated BL41 cell lines as well as their EBV-infected counterparts (BL2B95.8 and BL41B95.8). (b) Percentage of cells in G2M (M, mitosis) and sub-G1 phases was evaluated by flow cytometry cell cycle analysis (propidium iodide staining of total DNA content). (c) The same isoNH ${ }_{2} \mathrm{CA}-4$-treated cells were also analyzed by epifluorescence microscopy. Cells in M are indicated by *. Cells with fragmented nuclei are indicated by $\rightarrow$. Results are representative of three independent experiments

not shown). By flow cytometric fluorochrome-labeled inhibitors of capases (FLICA) assay, no activity was observed for caspase 3, 8 and 9 in BL41 cells treated with iso $\mathrm{NH}_{2} \mathrm{CA}-4$ (Figure 2b). In contrast, all three caspases were activated in iso $\mathrm{NH}_{2} \mathrm{CA}$-4-treated BL41B95.8 cells. Similar results were observed in BL2 and BL2B95.8 cell lines (data not shown). Short-term kinetic experiments showed that caspase 8 and 9 were simultaneously activated (data not shown). No increase in Fas or Fas ligand expression levels could be detected (data not shown).

To further dissect the apoptotic pathways induced in TP53mutated EBV-infected BL41 cells, mitochondrial potential was studied by flow cytometry, using 3,3'-dihexyloxacarbocyanine iodide (DiOC6(3)) as a selective probe for intact mitochondria. 
a

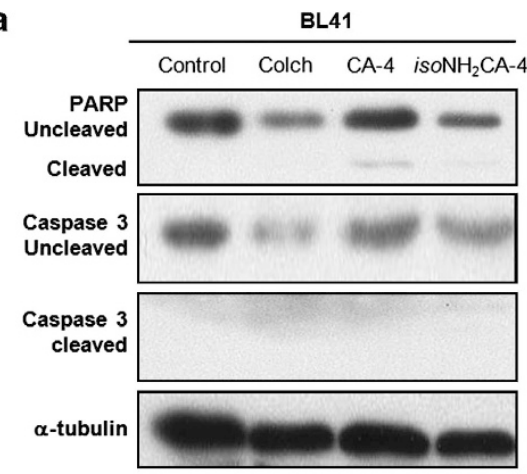

b
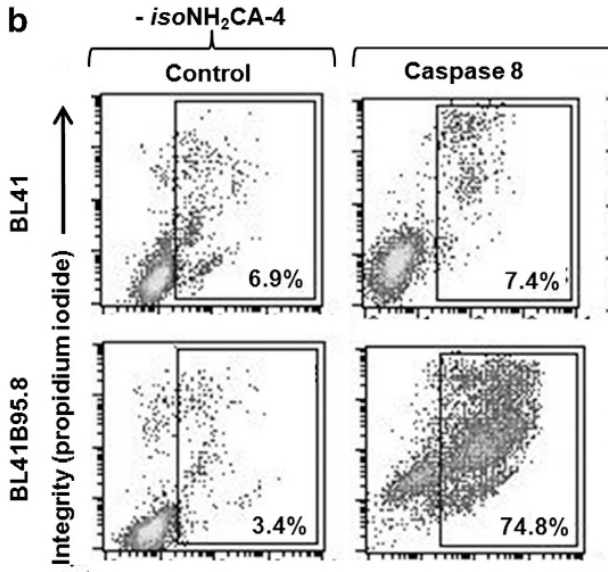

+ iso $\mathrm{NH}_{2} \mathrm{CA}-4$

BL41B95.8

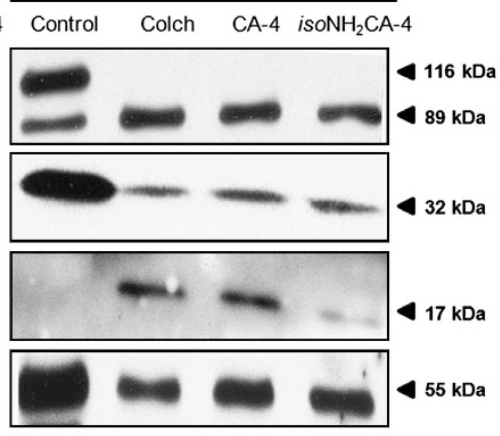

Caspase activity (FLICA)
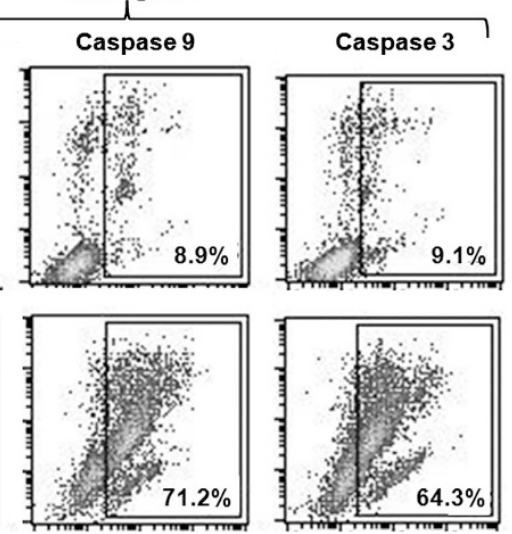

Figure 2 Apoptosis induced by spindle poisons in EBV-infected BL41B95.8 cells is caspase 3, 8 and 9 dependent. BL41 and BL41B95.8 cells were treated with colchicine $(20 \mathrm{nM}), \mathrm{CA}-4(10 \mathrm{nM})$ or isoNH $\mathrm{N}_{2} \mathrm{CA}-4(5 \mathrm{nM})$ for $24 \mathrm{~h}$. (a) PARP and caspase 3 cleavage as well as $\alpha$-tubulin (loading control) were analyzed by western blot. (b) Detection of caspase 8, 9 and 3 activation was evaluated by flow cytometry using the caspase-specific FLICA assay. Results are representative of three independent experiments

Results are given for IsoNH $\mathrm{NH}_{2} \mathrm{CA}-4$ (Figure 3a). Different concentrations of iso $\mathrm{NH}_{2} \mathrm{CA}-4(5,7.5$ and $10 \mathrm{nM})$ were used. Percentages of cells with weak staining of DiOC6(3) (due to mitochondrial transmembrane potential loss) were increased for all cell lines, except for BL41. At $5 \mathrm{nM}$ iso $\mathrm{NH}_{2} \mathrm{CA}-4$, EBV promoted the loss of mitochondrial transmembrane potential in both infected BL cell lines when compared with their EBVnegative counterparts. Similar results were obtained for colchicine and CA-4 (data not shown). Colocalization of Bax with the mitochondrial marker TOM20 by confocal microscopy (relocalization of Bax to mitochondria) was observed only in isoNH2CA-4-treated BL41B95.8 cells (Figure 3b). Similar results (Bax relocalization with isoNH2CA-4 treatment) were observed for BL2 and BL2B95.8 cell lines (data not shown).

EBV restored spindle poison-induced apoptosis in TP53-inactivated cells. Altogether, data presented in Figures 1-3 indicate that EBV rendered the TP53-mutated BL41 cell line sensitive to cytotoxic effects of spindle poisons. We thus hypothesized that EBV could bypass resistance to spindle poison apoptosis induction of TP53-mutated BL41 cells. To test this hypothesis, we transfected wild-type TP53 BL2 and BL2B95.8 cells with small interfering RNAs (siRNAs) against the TP53 mRNA and treated them or not with IsoNH $\mathrm{NH}_{2} \mathrm{CA}-4$. Apoptosis of treated BL2 cells was significantly decreased in presence of TP53 siRNAs
(Figure 4a), showing the functional importance of this protein in apoptosis induction by mitotic spindle poisons. Apoptotic BL2B95.8 cells were markedly increased after treatment with Iso $\mathrm{NH}_{2} \mathrm{CA}-4$ and were not significantly decreased in presence of TP53 siRNAs (Figure 4b). This result suggests that EBV was able to sensitize cells to apoptosis induced by IsoNH $\mathrm{N}_{2} \mathrm{CA}-4$ independently from TP53.

Inhibitors of P38 and JNK mitogen-activated protein kinases decreased apoptosis induced by EBV in TP53mutated cells treated with iso $\mathrm{NH}_{2} \mathrm{CA}-4$. Bax relocation to mitochondrial membranes can be obtained not only after TP53 activation but also after activation of both p38 and JNK mitogen-activated protein (MAP) kinases, and these kinases can be activated by EBV (through latent membrane protein 1 (LMP1) and LMP2A). We thus treated BL41B95.8 cells for 24 or $48 \mathrm{~h}$ with $10 \mathrm{nM}$ isoNH $\mathrm{NH}_{2} \mathrm{CA}-4$, after $1 \mathrm{~h}$ of pretreatment or not with p38 inhibitor (SB203580), JNK inhibitor (SP600125) or both together. Pretreatment with inhibitors decreased percentages of annexin-V-positive BL41 cells, an effect that was additive (Figures $5 \mathrm{a}$ and $\mathrm{c}$ ). Percentages of cells with weak mitochondrial potential (DiOC(6)3 staining) decreased when cells were pretreated with $\mathrm{p} 38$, JNK or both inhibitors (Figure $5 \mathrm{~b}$ ). Similar annexin-V and $\mathrm{DiOC}(6) 3$ results were obtained for BL2B95.8 cells (Figure $5 \mathrm{c}$ and data not shown). Altogether, these results suggest that p38 and JNK were 
a

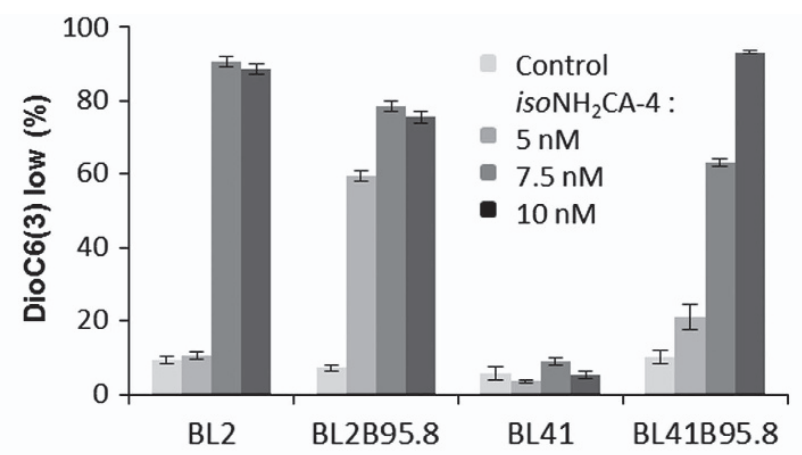

b
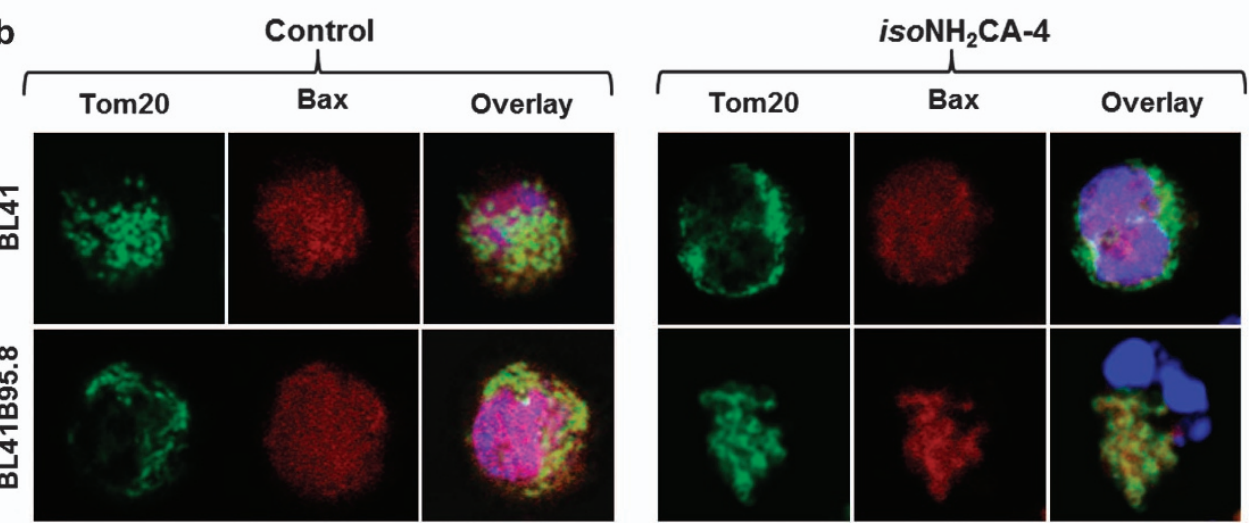

Figure 3 Mitochondria have a pivotal role in apoptosis induced by isoNH ${ }_{2} \mathrm{CA}-4$ in EBV-infected BL41B95.8 cells. Cells were treated with $5,7.5$ or $10 \mathrm{nM}$ iso $\mathrm{NH}_{2} \mathrm{CA}-4$ for $24 \mathrm{~h}$. (a) Mitochondrial integrity was evaluated by flow cytometry using DiOC6(3) staining of BL2- and TP53-mutated BL41 cell lines and their EBV-infected counterparts (BL2B95.8 and BL41B95.8). (b) For BL41 and BL41B95.8 cells treated with $10 \mathrm{nM}$ isoNH $2 \mathrm{CA}-4$ for $24 \mathrm{~h}$, colocalization of Bax with the mitochondrial marker Tom20 was studied by confocal microscopy (original magnification $\times 630$ ). Results are the mean of three independent experiments

involved in spindle poison-induced apoptosis of EBV-infected cells.

EBV sensitized TP53-mutated BL41 cells to apoptosis induction by any class of spindle poisons, an effect partially reversed by P38 and JNK MAP kinase inhibitors. We examined whether inhibition of p38 and JNK MAP kinases also decreased apoptosis sensitization when cells were treated with other classes of spindle poisons. We used taxol (taxane-binding site), a representative actin-stabilizing agent. For destabilizing actin drugs, analyses were performed with reference molecules for colchicine-binding domains (colchicine and CA-4) and vinca-binding domains (vinblastine and vincristine). Similar to colchicine, $\mathrm{CA}-4$ or iso $\mathrm{NH}_{2} \mathrm{CA}-4$, no apoptosis was observed for BL41 cells treated with taxol, vinblastine or vincristine, according to annexin-V/propidium iodide and DiOC6(3)/TOPRO-3 tests (Figure 6). In contrast, percentages of annexin-V-positive or DiOC6(3) weak BL41B95.8 cells were increased after treatment with any spindle poison. Treatment with p38 and JNK inhibitors systematically decreased the percentage of apoptotic cells (Figure 6). These results suggest that EBV-infected cells render TP53-mutated BL cells sensitive to apoptosis induction by all classes of spindle poisons tested, an effect likely to be caused by activation of p38 and JNK MAP kinases.

Activation of P38 and JNK MAP kinases sensitized EBV-negative TP53-mutated cells to apoptosis. Having shown that p38 and JNK inhibitors decreased apoptosis induced by spindle poisons in TP53-mutated EBV-infected cells, we treated or not BL41 cells with iso $\mathrm{NH}_{2} \mathrm{CA}-4$ and sphingosine, a p38/JNK activator. Results, presented in Figure 7, show that sphingosine sensitized TP53-mutated BL41 cells to iso $\mathrm{NH}_{2} \mathrm{CA}-4$-induced apoptosis (Figure 7). To check the specificity of the sphingosine effect on p38 and JNK activation, the same experiment was repeated in the presence of p38 and JNK inhibitors. Sphingosine treatment no longer sensitized TP53-mutated BL41 cells to iso $\mathrm{NH}_{2} \mathrm{CA}$ 4-induced apoptosis (Figure 7b). This confirms that p38 and JNK were indeed activated by dihydrosphingosine and responsible for $\mathrm{BL} 41$ cell apoptosis after iso $\mathrm{NH}_{2} \mathrm{CA}-4$ treatment. In a next step, we assayed two other TP53deficient K562 (myeloid lineage) and Jurkat (T-cell lineage) cell lines. Results show that dihydrosphingosine treatment was able to induce cell death on its own (Figures 7c and d). This indicates that according to cell type, p38 and JNK MAP kinase activation may be sufficient to induce the death of TP53-deficient tumor cells, without help from spindle poisons.

\section{Discussion}

Inactivation of TP53 may contribute to apoptosis resistance in most types of cancers. Bypassing resistance to apoptosis caused by TP53 inactivation is an important issue. We discovered that, when cells were infected with EBV, apoptosis can be induced by spindle poisons in TP53-mutated BL cell lines. We showed that p38 and JNK apoptotic MAP kinases were responsible for this reversion. 
a

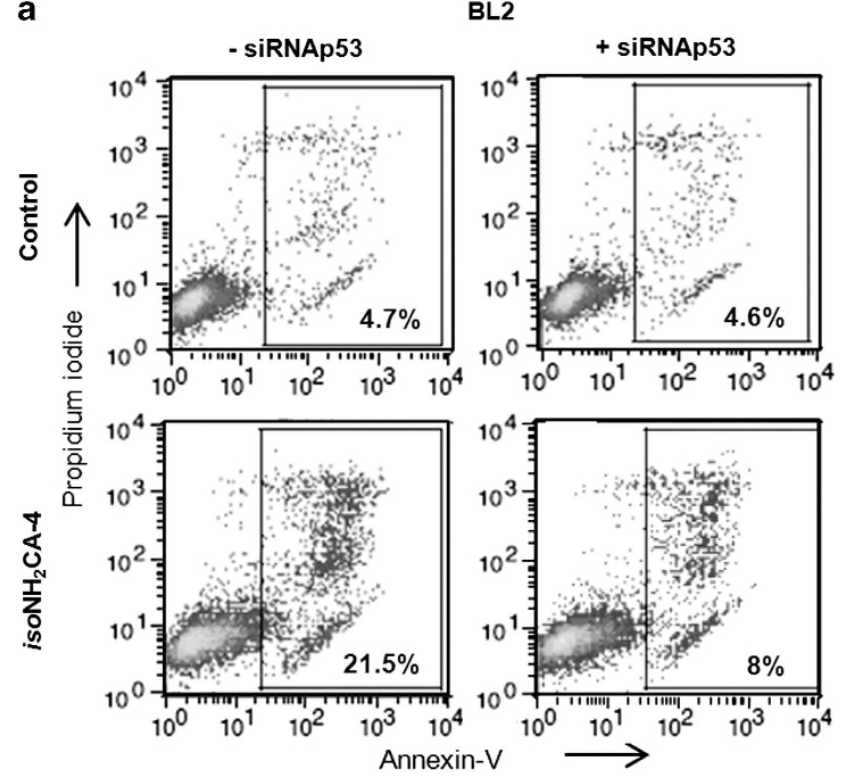

b

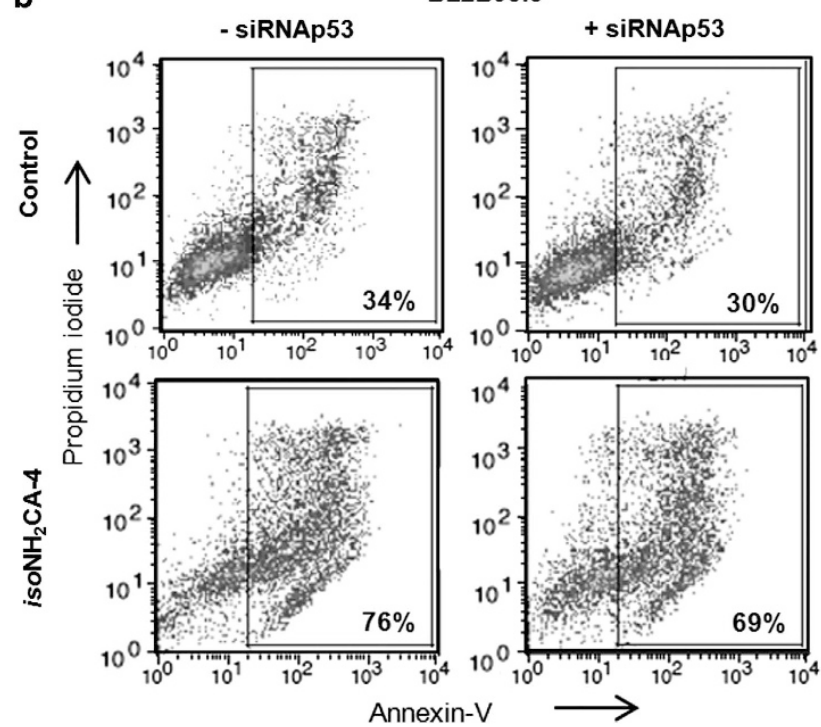

Figure 4 Apoptosis is induced in EBV-infected BL2 cells treated with iso $\mathrm{NH}_{2} \mathrm{CA}-4$ after TP53 downregulation. Downregulation of TP53 expression was obtained (+ siRNAp53) or not ( - siRNAp53) by transfection of BL2 (a) and BL2B95.8 (b) cells with either small interfering RNA (siRNA) against TP53 mRNA or scramble siRNA, respectively. Apoptosis induction as evaluated by flow cytometry (Annexin-V labeling). Cells were treated with $10 \mathrm{nM}$ of $I s \mathrm{NH}_{2} \mathrm{CA}-4$. Results are representative of three independent experiments

The TP53 protein is a well-characterized tumor suppressor protein, encoded by the TP53 gene, located on the short arm of chromosome 17 (17p13.1). ${ }^{20}$ It has a key role in cell cycle regulation, development, differentiation, gene amplification, DNA recombination, chromosome segregation and cell senescence. ${ }^{21,22}$ Following DNA damage, TP53 upregulates expression of genes involved in cell cycle arrest and DNA repair. If damage cannot be resolved, TP53 can induce intrinsic apoptosis by upregulation of pro-apoptotic genes, such as BH3-only proteins (PUMA, Noxa or Bid), Bax and Apaf-1. ${ }^{23-25}$ TP53 is also stabilized by phosphorylation following JNK pathway activation by cell stress-inducing signals, such as mitotic inhibitors.

Inactivation of TP53 is either due to genetic alterations (mutation or deletion) or due to functional inhibition, by dysregulation of the p19/ARF-mouse double minute 2 homolog (MDM2) axis. TP53 inactivation has been reported in more than $60 \%$ of human primary cancers. Hematological malignancies and leukemia exhibit a lower incidence $(<20 \%)$, but prognosis of this secondary genetic event is systematically unfavorable. ${ }^{26}$ Among $B$ lymphomas, the incidence of TP53 mutation is highest for chronic lymphocytic leukemia (CLL) (15\%), Richter's syndrome (CLL complication, 40\%), B high upgrade lymphomas (30\%) and BL (40\%). ${ }^{27}$

Loss of TP53 activity is responsible for cancer progression and resistance to chemotoxic drugs that induce apoptosis, including spindle poisons. ${ }^{28}$ Different strategies such as gene therapy (introduction of a wild-type TP53), immunotherapy (TP53 vaccines) and drug therapy (disruption of TP53 interaction with its inhibitor MDM2 by small molecules such as nutilin-3b, 5,5'-(2,5-furandiyl) bis-2-thiophenemethanol (RITA), 2,2-bishydroxymethyl-1-aza-bicyclo[2.2.2]octan-3-one (PRIMA-1) or 9-ethyl- $\mathrm{N}$-methyl-9H-carbazole-3-methanamine hydrochloride (Phikan083), have been examined to restore TP53-mediated apoptosis. ${ }^{29-31}$

Another way to restore apoptosis is via induction of a TP53-independent pathway in TP53-mutated cells. As reported in some studies, apoptosis has been induced in malignant $B$ and $T$ lymphocytes with arsenic trioxide by mitochondrial membrane potential collapse. ${ }^{32}$ PRIMA-1 has been shown to induce apoptosis in colorectal cell line through the JNK pathway. ${ }^{33}$ The BH3-only protein PUMA (a JNK substrate) can kill cells by apoptosis with or without TP53. ${ }^{34}$ Fenretinide, a synthetic retinoid derivative, increases intracellular levels of ceramide (a p38 and JNK inducer), which is metabolized to GD3, leading to oxidative stress via induction of the transcription factor Gadd153, Bak and intrinsic apoptosis. ${ }^{35}$ Moreover, it has been shown that overexpression of the eukaryotic translation initiation factor $5 \mathrm{~A} 1$ in lung cancer cells is associated with p38 and JNK signaling, which in turn could induce apoptosis independently of TP53 activity. ${ }^{36}$

EBV is a member of the gamma herpes virus family. It is one of the most common human viruses, as it infects as many as $95 \%$ of adults. ${ }^{37}$ After primary infection, classically during infancy, the latent viral infection is maintained throughout life in resting memory $B$ cells. Even if EBV immortalizes $B$ cells both in vitro and in vivo, its persistence is due to the host/virus equilibrium that keeps the infected cells under the continuous cytotoxic pressure of the host immune system. ${ }^{38,39}$ Rupture of this equilibrium may lead to EBV-associated lymphoproliferative syndromes. EBV is also associated with various cancers (nasopharyngeal carcinomas, BLs, Hodgkin's lymphomas, T-cell lymphomas and immunodeficiency-related B-cell lymphomas). ${ }^{40}$ In vitro, EBV immortalization of primary B cells is due to the proliferating program (so-called latence III), which corresponds to the expression of the full range of viral latent proteins. Among them, LMP1 (the major viral oncoprotein) and LMP2A possess conflicting functions, as they constitutively activate cell proliferation and survival pathways, as well as pro-apoptotic pathways. ${ }^{41-44}$ Indeed, we previously 


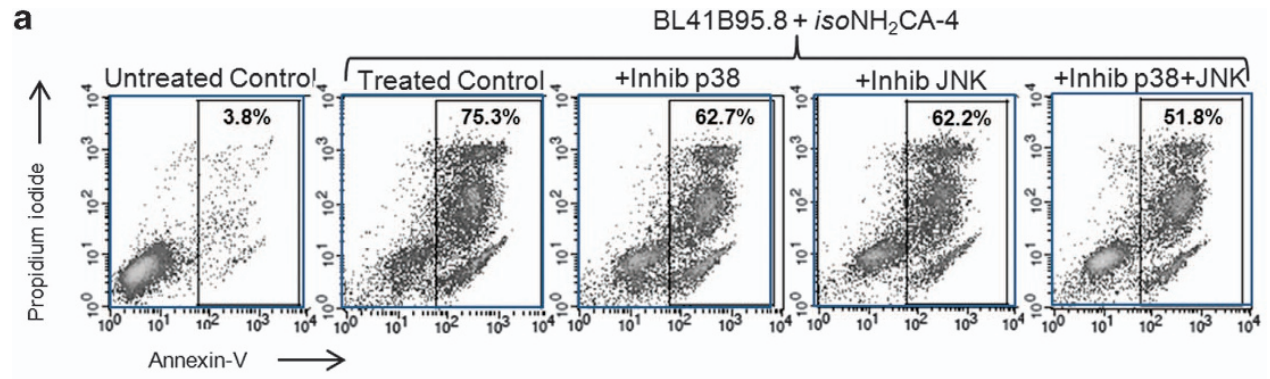

b

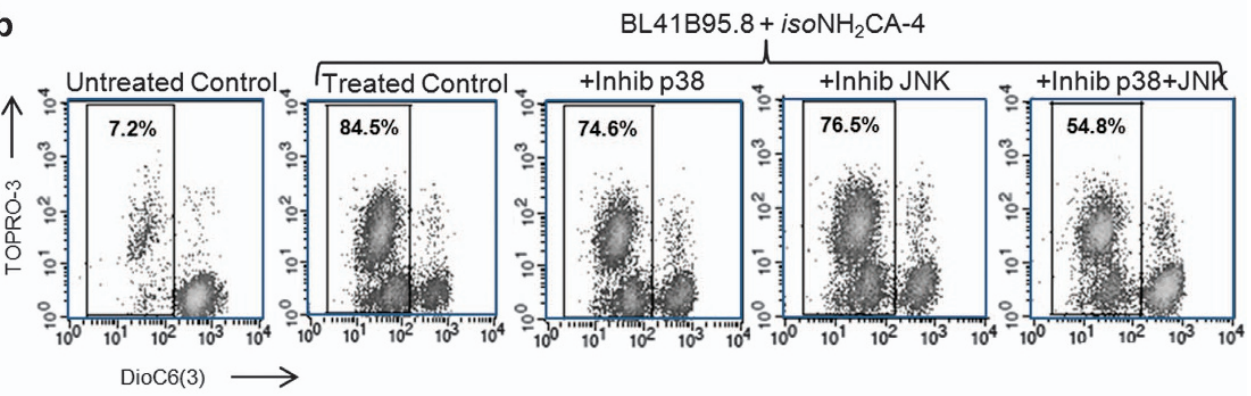

C
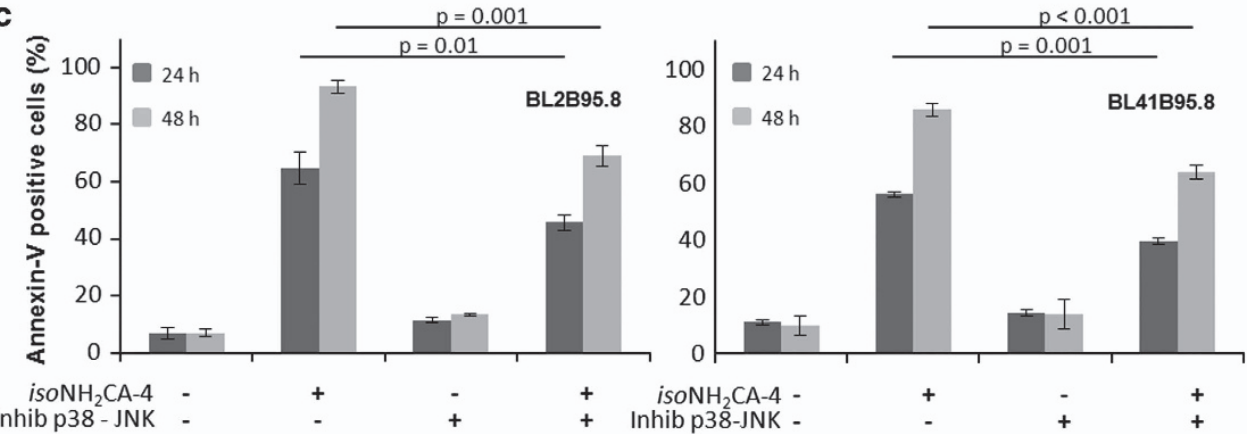

Figure 5 p38 and JNK MAP kinase inhibition decreases apoptosis induced by isoNH ${ }_{2} \mathrm{CA}-4$ in EBV-infected BL41B95.8 cells. Cells were treated with $10 \mathrm{nM}$ isoNH $\mathrm{NH}_{2} \mathrm{CA}-4$ with or without $1 \mathrm{~h}$ pretreatment with the p38 inhibitor SB203580 $(25 \mu \mathrm{M})$, the JNK inhibitor SP600125 $(7.5 \mathrm{nM})$ or both. (a and $\left.\mathbf{b}\right)$ An example of apoptosis induction and mitochondrial loss of integrity in BL41B95.8 cells as assessed on flow cytometry biparametric histogram after annexin- $\mathrm{V}$ and propidium iodide (a) or DiOC6(3) and propidium iodide (b) labeling. Percentages of apoptotic cells are indicated in each graph. (c) Percentages of BL2B95.8 (left panel) and BL41.B95.8 (right panel) annexin-V-positive cells in presence $(+)$ or absence $(-)$ of iso $\mathrm{NH}_{2} \mathrm{CA}-4$ and/or both $\mathrm{p} 38$ and JNK inhibitors at 24 and $48 \mathrm{~h}$. Results are representative of three independent experiments

demonstrated that, depending on the cell context, the EBV latency III program may also promote B-cell apoptosis as well interactions between the infected $B$ cells and killing T lymphocytes. ${ }^{45,46}$ As demonstrated in our study, EBV also potentiated spindle poison-induced apoptosis in a TP53independent manner. EBV induced reversion of apoptotic resistance to mitotic spindle poison treatments in TP53-mutated $B$ cells by activation of the MAPK JNK and p38 pathways.

p38 and JNK pathways have an essential role in intrinsic apoptosis induction particularly via molecules of the $\mathrm{Bcl} 2$ family. These pathways contribute to activation of the proapoptotic $\mathrm{BH} 3$-only molecules $\mathrm{Bim}$ and $\mathrm{Bmf},{ }^{47,48}$ responsible for Bax activation and thereafter permeabilization of the mitochondrial membrane. P38 and JNK pathways also inactivate the anti-apoptotic $\mathrm{Bcl} 2$ and $\mathrm{Bcl}-\mathrm{xl}$ proteins by phosphorylation. ${ }^{6,49-51}$ Other pro-apoptotic molecules are also targets for JNK-mediated phosphorylation, such as the histone guardian of the genome $\mathrm{H} 2 \mathrm{AX}{ }^{52}$ This suggests that JNK and p38 pathways can directly induce intrinsic apoptosis. Sphingoid bases (sphingosine and sphinganine) can potentiate apoptosis in breast ${ }^{53}$ and colon cancer cells $\mathrm{s}^{54}$ in a TP53-independent manner. Our results showed that chemical activation of p38 and JNK pathways with sphingosine could bypass apoptosis resistance to spindle poisons in TP53-mutated B cells.

The effect of p38/JNK MAP kinase activation on tumor cell death may depend on the cell lineage. Indeed, dihydrosphyngosine treatment of BL41 TP53-mutated cells marginally induced cell death, whereas it strongly decreased cell viability of K562 and Jurkat cells. As expected, EBV activation of $\mathrm{p} 38 / \mathrm{JNK}$ MAP kinase did not promote BL cell death on its own. In that case, apoptotic potential of p38/JNK MAP kinase activation was revealed by spindle poison treatment. On one hand, it can be put forward that apoptotic potential of p38/JNK MAP kinase activation by EBV was masked by other latency proteins that induce anti-apoptotic pathways such as NF-кB (nuclear factor kappa-light-chain-enhancer of activated $B$ cells) activation or Bcl2 overexpression. On the other hand, these differences between cell lines could be due to differences in energetic metabolism and aerobic glycolysis. 


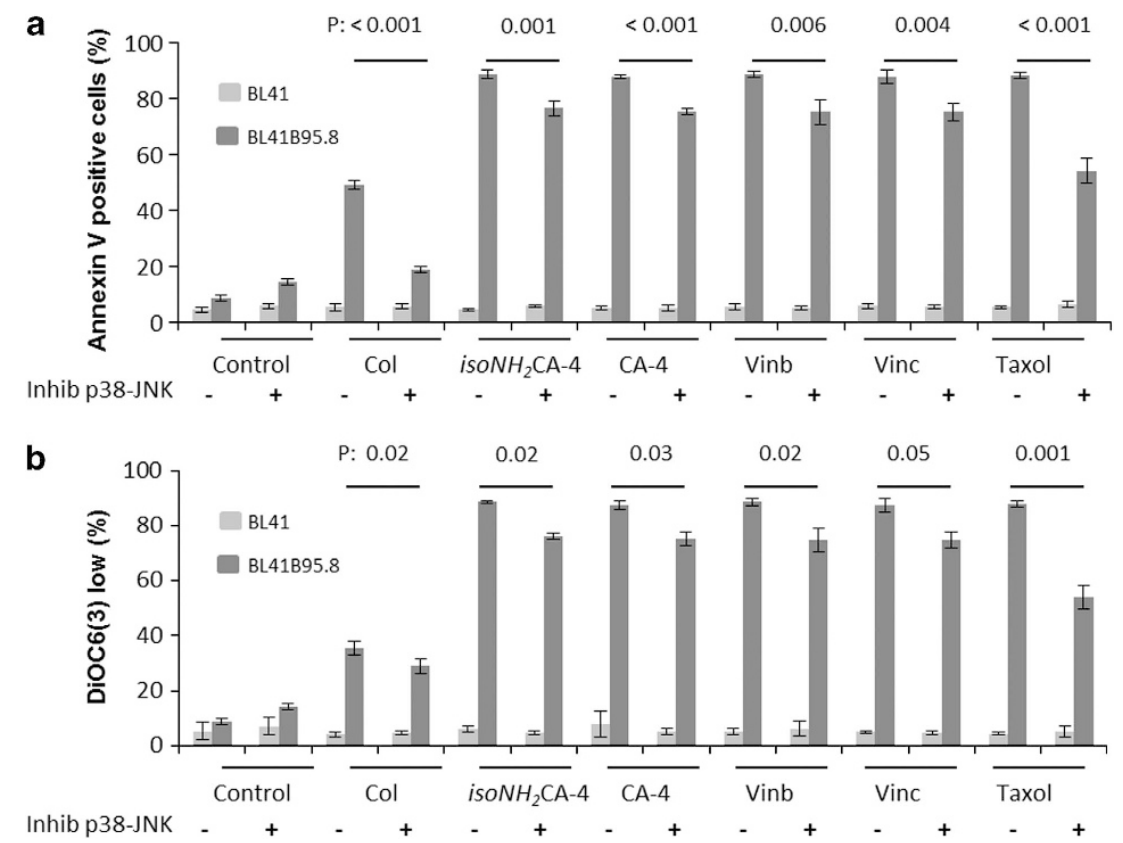

Figure 6 p38 and JNK inhibitors counteract apoptosis induced by any class of spindle poisons in EBV-positive BL41B95.8 cells. BL41 and BL41B95.8 cells were treated with actin-stabilizing (Taxol) or with actin-destabilizing drugs specific for the colchicine site (colchicine: $30 \mathrm{nM} \mathrm{Col} ; 10 \mathrm{nM}$ (isoN $\mathrm{NH}_{2} \mathrm{CA}-4$, isoCA-4); $\left.20 \mathrm{nM} \mathrm{CA}-4\right)$ or the vinca site (vinblastine: $25 \mathrm{nM}$ Vinb; vincristine: $25 \mathrm{nM}$ Vinc) for $24 \mathrm{~h}$. Cells were additionally pretreated ( + ) or not ( -$)$ for $1 \mathrm{~h}$ with the p38 inhibitor SB203580 $(25 \mu \mathrm{M})$ and the JNK inhibitor SP600125 (7.5 nM). (a) Percentages of BL41 and BL41B95.8 annexin-V-positive cells assessed by flow cytometry. (b) Percentages of DiOC6(3) negative cells, assessed by flow cytometry. These results correspond to at least three independent experiments

Permeability transition pore complex (PTPC) opening and closing not only involves molecules of the Bcl2 family, such as Bax or Bcl2, but also mitochondrial bioenergetic. ${ }^{55} \mathrm{~A}$ hallmark of tumor cells is their increased consumption of glucose and their switch of energy supply from oxydative phosphorylation to aerobic glycolysis (the Warburg effect), which is essential for tumor biomass increase. Hexokinase II, a mitochondrial protein that catalyses the first step of glycolysis, inhibits PTPC opening. Moreover, aerobic glycolysis leads to intracellular $\mathrm{pH}$ increase, favouring caspase inactivation. Overexpression of glycolytic genes is due to oncogene activation (such as c-Myc or RAS), functional loss of tumor suppressor (such as TP53 or phosphatase and tensin homolog), even in the presence of oxygen, or hypoxia. ${ }^{56}$ The Warburg effect has been found in most, if not all, types of malignant tumors, including hematological malignancies, with a possible prognostic value. ${ }^{57}$ Aerobic glycolysis level combined with TP53 status could thus influence sensitivity to apoptotic cell death induced by p38 and JNK MAP kinase activation. In that sense it would be interesting to test the effect of p38/JNK MAP kinase activation on other cancer models such as epithelial tumor cells, as these cells are characterized by extensive cytoplasmic modifications that contribute to resistance to apoptosis.

In conclusion, we showed that resistance to spindle poisoninduced apoptosis of TP53-mutated tumor cells can be bypassed by EBV or by chemical agents such as sphingosine derivatives, which activate JNK and p38 pathways that in turn induce the intrinsic mitochondrial apoptosis pathway. These results may lead to new combinatorial therapeutic strategies for patients with tumors carrying deletions of parts of the short arm of chromosome 17 (del17p).

\section{Materials and Methods}

Cell lines, drugs and chemical treatments. K562 (myeloid tumor cell line), Jurkat (lymphoma T-cell line), BL2 and BL41 (EBV-negative BL B-cell lines) and their EBV-infected counterparts (infected with EBV wild-type strain B 95.8), BL2.B95.8 and BL41 B95.8 were cultured in RPMI 1640 medium (Lonza, Verviers, Belgium), supplemented with $100 \mathrm{U} / \mathrm{ml}$ penicillin, $100 \mu \mathrm{g} / \mathrm{ml}$ streptomycin, $1 \mathrm{mM}$ sodium pyruvate, $1 \%$ nonessential amino acids, $2 \mathrm{mM} \mathrm{L-glutamine} \mathrm{(All} \mathrm{from} \mathrm{Gibco}$ BRL, Fisher, Illkirch, France) and 10\% fetal calf serum (Lonza) and maintained in a $5 \% \mathrm{CO}_{2}$ incubator at $37^{\circ} \mathrm{C}$. Cells were treated with antimitotic tubulin poisons: colchicine, CA-4 and iso-amino CA-4 (iso $\mathrm{NH}_{2} \mathrm{CA}-4$ ) from CNRS, BioCIS UMR 8076, Therapeutic Chemistry Laboratory, Faculty of Pharmacy, Chatenay-Malabry, France, as well as with vinblastine (Alloga, Marseille, France), vincristine and taxol (the two from Hospira, Meudon la Forêt, France). Treatment duration and drug concentrations varied and are indicated in legends. Cells were pretreated or not with the p38 inhibitor SB203580 $(25 \mu \mathrm{M})$ (Calbiochem, VWR, Strasbourg, France), the JNK inhibitor SP600125 (7.5nM) (Sigma-Aldrich, Saint Quentin Fallavier, France) or D-erythro-dihydrosphingosine $(7.5 \mu \mathrm{M})$ (Sigma-Aldrich) for $1 \mathrm{~h}$. All drugs were reconstituted in dimethyl sulfoxide (DMSO), used as control treatment.

Cytotoxicity and viability assays. MTS (3-(4,5-dimethylthiazol-2-yl)-5-(3carboxymethoxyphenyl)-2-(4-sulfophenyl)-2H-tetrazolium salt) cell proliferation assay, labeling of annexin- $\mathrm{V}$, propidium iodide staining for cellular DNA content and caspase activity (FLICA tests) were performed as previously described. ${ }^{19,46}$ Assessment of mitochondrial potential with DiOC6(3) was performed as follows: $1 \mu \mathrm{l}$ DiOC6(3) solution (0.5 $\mu \mathrm{M}$ in DMSO, Invitrogen, Fisher) was added to $500 \mu \mathrm{l}$ of cell suspension $\left(2.5 \times 10^{5}\right.$ cells) and incubated for $20 \mathrm{~min}$ at room temperature. Before flow cytometric analysis (on a FacsCalibur, Becton Dickinson, Franklin Lakes, NJ, USA), $1 \mu$ I TOPRO-3 ( $1 \mathrm{mM}$, Invitrogen) was added to each sample. $\mathrm{DiOC}(6) 3$ was excited with a 488-nm argon laser and TOPRO-3 with a 633-nm helium-neon laser. Fluorescence were collected with a $530 \pm 15$-nm band-pass filter for DiOC(6)3 and a 650-nm long-pass filter for TOPRO-3.

Immunofluorescence double staining for confocal microscopy and nuclei staining for epifluorescence microscopy

Immunostaining: Cells $\left(5 \times 10^{5}\right)$ were fixed on slides with $4 \%$ paraformaldehyde for $10 \mathrm{~min}$ at room temperature, washed with phosphate buffered saline 
a BL41-Without p38 / JNK inhib.

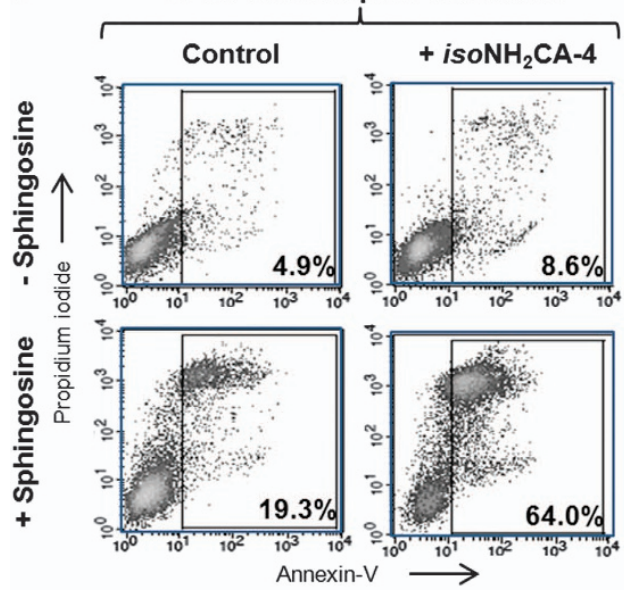

C

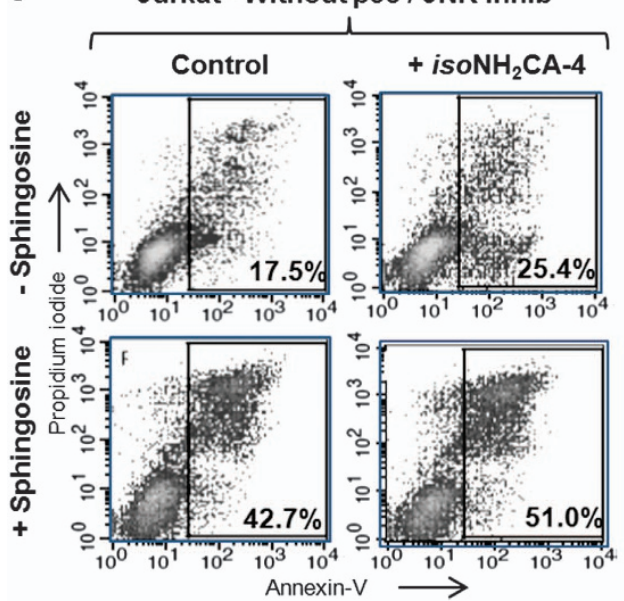

b

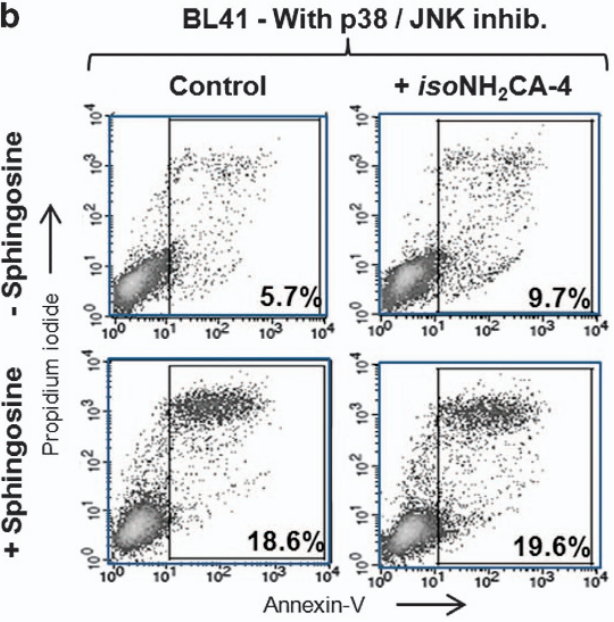

d
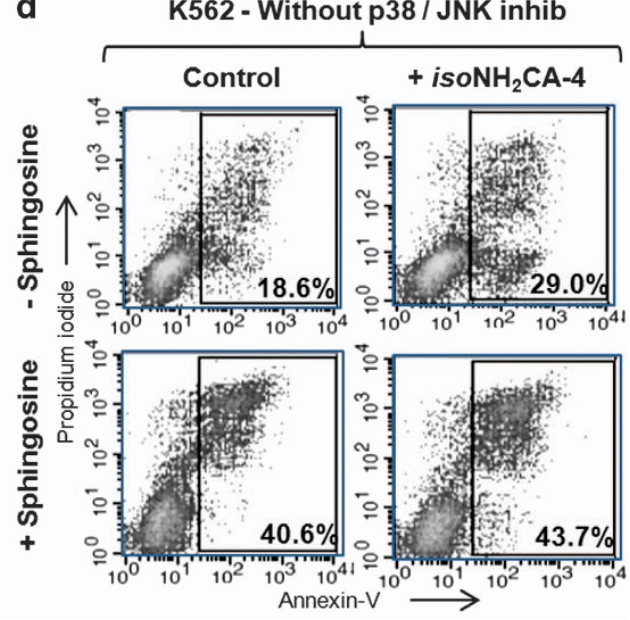

Figure 7 Dihydrosphingosine renders TP53-mutated and EBV-negative BL41 cells permissive to apoptosis. BL41 (a and b), Jurkat (c) and K562 (d) cells were pretreated or not for $1 \mathrm{~h}$ with dihydrosphingosine $(7.5 \mu \mathrm{M})$ and then treated or not with $10 \mathrm{nM}$ iso $\mathrm{NH}_{2} \mathrm{CA}-4$ for $24 \mathrm{~h}$. Apoptosis induction was evaluated by flow cytometry, after annexin-V and propidium iodide staining. Cells were pretreated with dihydrosphingosine in absence $(\mathbf{a}, \mathbf{c}$ and $\mathbf{d})$ or in presence (b) of both p38 and JNK inhibitors. Percentages of apoptotic cells are indicated in each graph. Results are representative of three independent experiments

(PBS), permeabilized with $100 \mu \mathrm{l} \quad 0.1 \%$ Triton $\mathrm{X}-100$ for $8 \mathrm{~min}$ at room temperature, washed with PBS and incubated for $20 \mathrm{~min}$ at room temperature with $2 \mu \mathrm{l}$ of primary Abs: anti-Bax lgG2b mAb (sc-7480) or its isotypic control (IgG2b mouse, sc-3879) and anti-Tom20 polyclonal Ab(FL-145) (sc-11415) or its isotypic control (IgG rabbit, sc-3888), all from Santa Cruz Cliniscience, Nanterre, France. Then, slides were washed with PBS and incubated with the secondary Abs: $1 \mu \mathrm{l}$ of Alexa Fluor 488 donkey anti-rabbit IgG and $1 \mu \mathrm{l}$ of Alexa Fluor $633 \mathrm{~F}\left(\mathrm{ab}^{\prime}\right) 2$ goat anti-mouse IgG (both from Invitrogen) for $20 \mathrm{~min}$ at room temperature. Slides were washed with PBS, and nuclei were counterstained with 4',6-diamidino-2-phenylindole (DAPI) $(1 \mathrm{mg} / \mathrm{mL})$. Images were collected using a Zeiss LSM-510 laser scanning confocal microscope (Zeiss, Marly-le-Roi, France). DAPI, Alexa Fluor 488 and Alexa Fluor 633 were excited with a 405-nm laser diode, a 488-nm argon laser and a 633-nm helium-neon laser, respectively. Fluorescence of DAPI, Alexa Fluor 488 and Alexa Fluor 633 were collected with a $420 \pm 30$-nm band-pass filter, $530 \pm 15-\mathrm{nm}$ band-pass filter and 650-nm long-pass filter, respectively. For epifluorescence microscopy (DMl 6000 B, Leica Microsystems, Nanterre, France), nuclei were stained with propidium iodide $(0.5 \mathrm{mg} / \mathrm{ml})$, after permeabilization of cells with $0.1 \%$ Triton X-100 diluted in PBS.

Western blotting. Total protein extracts were obtained as described. ${ }^{58}$ For western blots, primary antibodies were anti PARP (Rabbit polyclonal 9542, Cell signaling, at 1/1000), anti caspase 3 (Rabbit mAb 8G10, Cell signaling, St-Qentin-enYvelines, France at 1/1000), anti-cleaved caspase 3 (Rabbit polyclonal D175, Cell signaling, at 1/1000) and anti $\alpha$-tubulin (sc-23948, Santa Cruz at 1/200). Secondary horseradish peroxidase-conjugated goat anti-mouse or anti-rabbit immunoglobulins (Bio-Rad, Marnes-la-Coquette, France) were used at $1 / 5000$ for $1 \mathrm{~h}$

siRNA transfection. Double-stranded RNAs (21 nt) against TP53wt was chemically synthesized by Eurogentec (Angers, France) according to the previously published sequence: ${ }^{59} 5^{\prime}$-GCAGAACCGGAGGCCCAUdTdT-3'. A universal control $(\mathrm{CU})$ consisting in a scrambled sequence was purchased from Eurogentec. Transfections were done using the Amaxa cell optimization kit V (Lonza, Verviers, Belgium), following the Amaxa guidelines. Briefly, cells were re-suspended in Nucleofector $\mathrm{V}$ solution. siRNA $(2 \mu \mathrm{g})$ were added to cell suspensions $\left(7 \times 10^{6}\right.$ in $\left.100 \mu l\right)$, transferred into chambers and nucleofected using the R.013 program (Amaxa, Lonza).

\section{Conflict of Interest}

The authors declare no conflict of interest.

1. Henson PM, Bratton DL, Fadok VA. Apoptotic cell removal. Curr Biol 2001; 11: R795-R805.

2. Green DR, Kroemer G. The pathophysiology of mitochondrial cell death. Science 2004; 305: 626-629.

3. Kroemer G, Galluzzi L, Brenner C. Mitochondrial membrane permeabilization in cell death. Physiol Rev 2007; 87: 99-163. 
4. LaCasse EC, Mahoney DJ, Cheung HH, Plenchette S, Baird S, Korneluk RG. IAP-targeted therapies for cancer. Oncogene 2008; 27: 6252-6275.

5. Matson DR, Stukenberg PT. Spindle poisons and cell fate: a tale of two pathways. Mol Interv 2011; 11: 141-150.

6. Basu A, You SA, Haldar S. Regulation of Bcl2 phosphorylation by stress response kinase pathway. Int J Oncol 2000; 16: 497-500.

7. Kuppens IE. Current state of the art of new tubulin inhibitors in the clinic. Curr Clin Pharmacol 2006; 1: 57-70.

8. Jordan MA, Wilson L. Microtubules as a target for anticancer drugs. Nat Rev Cancer 2004; 4: 253-265.

9. Récher C, Coiffier B, Haioun C, Molina TJ, Fermé C, Casasnovas O et al. Intensified chemotherapy with ACVBP plus rituximab versus standard $\mathrm{CHOP}$ plus rituximab for the

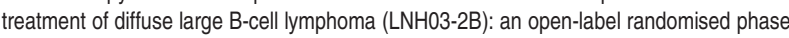
3 trial. Lancet 2011; 378: 1858-1867.

10. Yared JA, Tkaczuk KHR. Update on taxane development: new analogs and new formulations. Drug Des Devel Ther 2012; 6: 371-384.

11. Freilich RJ, Balmaceda C, Seidman AD, Rubin M, DeAngelis LM. Motor neuropathy due to docetaxel and paclitaxel. Neurology 1996; 47: 115-118.

12. Fojo T, Menefee M. Mechanisms of multidrug resistance: the potential role of microtubulestabilizing agents. Ann Oncol 2007; 18(Suppl 5): v3-v8.

13. Dumontet $\mathrm{C}$. Mechanisms of action and resistance to tubulin-binding agents. Expert Opin Investig Drugs 2000; 9: 779-788.

14. Cai SX. Small molecule vascular disrupting agents: potential new drugs for cancer treatment. Recent Pat Anticancer Drug Discov 2007; 2: 79-101.

15. Thomson P, Naylor MA, Everett SA, Stratford MRL, Lewis G, Hill S et al. Synthesis and biological properties of bioreductively targeted nitrothienyl prodrugs of combretastatin A-4. Mol Cancer Ther 2006; 5: 2886-2894.

16. Messaoudi S, Tréguier B, Hamze A, Provot $\mathrm{O}$, Peyrat JF, De Losada JR et al. Isocombretastatins a versus combretastatins a: the forgotten isoCA-4 isomer as a highly promising cytotoxic and antitubulin agent. J Med Chem 2009; 52 : 4538-4542.

17. Hamze A, Giraud A, Messaoudi S, Provot O, Peyrat J-F, Bignon J et al. Synthesis, biological evaluation of 1,1-diarylethylenes as a novel class of antimitotic agents. ChemMedChem 2009; 4: 1912-1924.

18. Cortes J, Vidal M. Beyond taxanes: the next generation of microtubule-targeting agents. Breast Cancer Res Treat 2012; 133: 821-830.

19. Chanut A, Duguet F, Marfak A, David A, Petit B, Parrens M et al. RelA and RelB cross-talk and function in Epstein-Barr virus transformed B cells. Leukemia 2014; 28: 871-879.

20. Levine AJ, Momand J, Finlay CA. The p53 tumour suppressor gene. Nature 1991; 351 453-456.

21. Lane DP. Cancer. p53, guardian of the genome. Nature 1992; 358: 15-16.

22. Oren M, Rotter V. Introduction: p53-the first twenty years. Cell Mol Life Sci 1999; 55 : $9-11$

23. Wu X, Deng Y. Bax and BH3-domain-only proteins in p53-mediated apoptosis. Front Biosci 2002; 7: d151-d156.

24. $\mathrm{Yu} \mathrm{J}$, Zhang $\mathrm{L}$. The transcriptional targets of $\mathrm{p} 53$ in apoptosis control. Biochem Biophys Res Commun 2005; 331: 851-858.

25. Sax JK, El-Deiry WS. p53 downstream targets and chemosensitivity. Cell Death Differ 2003; 10: 413-417.

26. Cheung K-JJ, Horsman DE, Gascoyne RD. The significance of TP53 in lymphoid malignancies: mutation prevalence, regulation, prognostic impact and potential as a therapeutic target. Br J Haematol 2009; 146: 257-269.

27. Imamura J, Miyoshi I, Koeffler HP. p53 in hematologic malignancies. Blood 1994; 84 2412-2421.

28. Lai D, Visser-Grieve S, Yang X. Tumour suppressor genes in chemotherapeutic drug response. Biosci Rep 2012; 32: 361-374.

29. Yu Q. Restoring p53-mediated apoptosis in cancer cells: new opportunities for cancer therapy. Drug Resist Updat 2006; 9: 19-25.

30. Suzuki K, Matsubara H. Recent advances in p53 research and cancer treatment. J Biomed Biotechnol 2011; 2011: 978312

31. Wong RSY. Apoptosis in cancer: from pathogenesis to treatment. J Exp Clin Cancer Res 2011; 30: 87.

32. Zhu XH, Shen YL, Jing YK, Cai X, Jia PM, Huang Y et al. Apoptosis and growth inhibition in malignant lymphocytes after treatment with arsenic trioxide at clinically achievable concentrations. J Natl Cancer Inst 1999; 91: 772-778.

33. Li Y, Mao Y, Brandt-Rauf PW, Williams AC, Fine RL. Selective induction of apoptosis in mutant p53 premalignant and malignant cancer cells by PRIMA-1 through the c-Jun-NH2kinase pathway. Mol Cancer Ther 2005; 4: 901-909.

34. Yu J, Zhang L. PUMA, a potent killer with or without p53. Oncogene 2008; 27(Suppl 1): S71-S83.

35. Corazzari M, Lovat PE, Oliverio S, Di Sano F, Donnorso RP, Redfern CPF et al. Fenretinide: a p53-independent way to kill cancer cells. Biochem Biophys Res Commun 2005; 331: 810-815.

36. Taylor CA, Zheng Q, Liu Z, Thompson JE. Role of $p 38$ and JNK MAPK signaling pathways and tumor suppressor p53 on induction of apoptosis in response to Ad-elF5A1 in A549 lung cancer cells. Mol Cancer 2013; 12: 35
37. Henle G, Henle W, Clifford P, Diehl V, Kafuko GW, Kirya BG et al. Antibodies to Epstein-Barr virus in Burkitt's lymphoma and control groups. J Natl Cancer Inst 1969; 43 $1147-1157$.

38. Thorley-Lawson DA. Epstein-Barr virus: exploiting the immune system. Nat Rev Immunol 2001; $1: 75-82$

39. Bornkamm GW, Hammerschmidt W. Molecular virology of Epstein-Barr virus. Philos Trans $R$ Soc Lond B Biol Sci 2001; 356: 437-459.

40. Middeldorp JM, Brink AA, van den Brule AJ, Meijer CJ. Pathogenic roles for Epstein-Barr virus (EBV) gene products in EBV-associated proliferative disorders. Crit Rev Oncol Hematol 2003; 45: 1-36

41. Busch LK, Bishop GA. The EBV transforming protein, latent membrane protein 1 mimics and cooperates with CD40 signaling in B lymphocytes. J Immunol 1999; 162 $2555-2561$.

42. Eder J. Tumour necrosis factor alpha and interleukin 1 signalling: do MAPKK kinases connect it all? Trends Pharmacol Sci 1997; 18: 319-322.

43. Lam N, Sugden B. CD40 and its viral mimic, LMP1: similar means to different ends. Cell Signal 2003; 15: 9-16.

44. Sandor F, Buc M. Toll-like receptors. II. Distribution and pathways involved in TLR signalling. Folia Biol (Praha) 2005; 51: 188-197.

45. Le Clorennec C, Youlyouz-Marfak I, Adriaenssens E, Coll J, Bornkamm GW, Feuillard J. EBV latency III immortalization program sensitizes B cells to induction of CD95-mediated apoptosis via LMP1: role of NF-kappaB, STAT1, and p53. Blood 2006 107: 2070-2078.

46. Le Clorennec C, Ouk TS, Youlyouz-Marfak I, Panteix S, Martin C-C, Rastelli J et al Molecular basis of cytotoxicity of Epstein-Barr virus (EBV) latent membrane protein 1 (LMP1) in EBV latency III B cells: LMP1 induces type II ligand-independent autoactivation of CD95/Fas with caspase 8-mediated apoptosis. J Virol 2008; 82 6721-6733.

47. Lei K, Davis RJ. JNK phosphorylation of Bim-related members of the Bcl2 family induces Bax-dependent apoptosis. Proc Natl Acad Sci USA 2003; 100: 2432-2437.

48. Piñon JD, Labi V, Egle A, Villunger A. Bim and Bmf in tissue homeostasis and malignant disease. Oncogene 2008; 27(Suppl 1): S41-S52.

49. Yamamoto $\mathrm{K}$, Ichijo $\mathrm{H}$, Korsmeyer SJ. BCL-2 is phosphorylated and inactivated by an ASK1/Jun N-terminal protein kinase pathway normally activated at G(2)/M. Mol Cell Biol 1999; 19: 8469-8478.

50. De Chiara G, Marcocci ME, Torcia M, Lucibello M, Rosini P, Bonini P et al. Bcl-2 Phosphorylation by p38 MAPK: identification of target sites and biologic consequences. J Biol Chem 2006; 281: 21353-21361.

51. Grethe S, Ares MPS, Andersson T, Pörn-Ares MI. p38 MAPK mediates TNF-induced apoptosis in endothelial cells via phosphorylation and downregulation of $\mathrm{Bcl}-\mathrm{x}(\mathrm{L})$. Exp Cell Res 2004; 298: 632-642.

52. Sluss HK, Davis RJ. H2AX is a target of the JNK signaling pathway that is required for apoptotic DNA fragmentation. Mol Cell 2006; 23: 152-153.

53. Ahn EH, Chang CC, Schroeder JJ. Evaluation of sphinganine and sphingosine as human breast cancer chemotherapeutic and chemopreventive agents. Exp Biol Med (Maywood) 2006; 231: 1664-1672

54. Ahn EH, Schroeder JJ. Induction of apoptosis by sphingosine, sphinganine, and $\mathrm{C}(2)$-ceramide in human colon cancer cells, but not by $\mathrm{C}(2)$-dihydroceramide. Anticancer Res 2010; 30: 2881-2884.

55. Indran IR, Tufo G, Pervaiz S, Brenner C. Recent advances in apoptosis, mitochondria and drug resistance in cancer cells. Biochim Biophys Acta 2011; 1807: 735-745.

56. Zheng J. Energy metabolism of cancer: Glycolysis versus oxidative phosphorylation. Oncol Lett 2012; 4: 1151-1157.

57. Leni Z, Parakkal G, Arcaro A. Emerging metabolic targets in the therapy of hematologica malignancies. Biomed Res Int 2013; 2013: 946206

58. Durand-Panteix S, Farhat M, Youlyouz-Marfak I, Rouaud P, Ouk-Martin C, David A et al. $\mathrm{B} 7-\mathrm{H} 1$, which represses EBV-immortalized B cell killing by autologous $\mathrm{T}$ and NK cells, is oppositely regulated by c-Myc and EBV latency III program at both mRNA and secretory lysosome levels. J Immunol 2012; 189: 181-190.

59. Martinez LA, Naguibneva I, Lehrmann H, Vervisch A, Tchénio T, Lozano G et al. Synthetic small inhibiting RNAs: efficient tools to inactivate oncogenic mutations and restore p53 pathways. Proc Natl Acad Sci USA 2002; 99: 14849-14854.

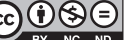

Cell Death and Disease is an open-access journal published by Nature Publishing Group. This work is licensed under a Creative Commons Attribution-NonCommercialNoDerivs 3.0 Unported License. The images or other third party material in this article are included in the article's Creative Commons license, unless indicated otherwise in the credit line; if the material is not included under the Creative Commons license, users will need to obtain permission from the license holder to reproduce the material. To view a copy of this license, visit http://creativecommons.org/licenses/ by-nc-nd/3.0/ 